\title{
ENTANGLED MEMORY: TOWARD A THIRD WAVE IN MEMORY STUDIES ${ }^{1}$
}

\author{
GREGOR FEINDT, FÉLIX KRAWATZEK, DANIELA MEHLER, \\ FRIEDEMANN PESTEL, AND RIEKE TRIMÇEV
}

\begin{abstract}
This essay takes up the call for a "third phase" in memory studies and makes theoretical and methodological suggestions for its further development. Starting from an understanding of memory that centers on memory's temporality, its relation to language, and its quality as a social action, the essay puts forward the concept of "entangled memory." On a theoretical level, it brings to the fore the entangledness of acts of remembering. In a synchronic perspective, memory's entangledness is presented as twofold. Every act of remembering inscribes an individual in multiple social frames. This polyphony entails the simultaneous existence of concurrent interpretations of the past. In a diachronic perspective, memory is entangled in the dynamic relation between single acts of remembering and changing mnemonic patterns. Memory scholars therefore uncover boundless crossreferential configurations. Wishing to enhance the dialogue between the theoretical and the empirical parts of memory studies, we propose four devices that serve as a heuristic in the study of memory's entanglement: chronology against time, conflict, generations, and self-reflexivity. Current debates on European memory permit us to explore the possible benefits that the concept of entangled memory carries for memory studies.
\end{abstract}

Keywords: collective memory, memory studies, histoire croisée, hermeneutics, postnational condition, plurality, layers of time, European identity, reflexivity

Memory studies have entered a critical moment. The successive consolidation and professionalization of the discipline as well as the multiplication of empirical explorations have contributed significantly to an increased understanding of processes of remembering, their political salience, and challenges, particularly during moments of change. Coining this the "third phase" of memory studies, some critical voices have also emerged to rightly warn us about the risks of memory studies turning into an additive empirical exercise without much theoretical improvement. ${ }^{2}$

1. This article substantially benefited from remarks by Jörn Leonhard, Iain MacKenzie, and Jeffrey $\mathrm{K}$. Olick as well as the anonymous reviewers of History and Theory. We are furthermore indebted to the participants in a workshop at the Centre for Interdisciplinary Studies in Bielefeld on "European Memory?" in July 2011, where we were able to discuss an earlier version of this article in detail. The authors remain jointly responsible for any remaining flaws.

2. The "first phase" is commonly, although simplistically, linked with Maurice Halbwachs's work La mémoire collective [1950] (Paris: Presses universitaires de France,1997); Les cadres sociaux de la mémoire (Paris: Librairie Félix Alcan, 1925). A second one began around the publication of Pierre Nora's and Jan Assmann's works in the 1980s and early 1990s: Pierre Nora, Les lieux de mémoire, 7 
Astrid Erll, for instance, pertinently argues that a simplistic understanding of culture as a reified, clear-cut, territory-based concept has driven memory studies: "What was studied was the culture, and the memory, of $a$ social formation: a religious group, a social class, an ethnicity." Indeed, even at the beginning of this "third phase", proponents of memory studies have widely assumed the homogeneity of the commemorating groups and privilege tangible manifestations of memory. This article will take up recent scholarship that has criticized these assumptions as overly simplistic and takes the debate one step further to a third phase by approaching memory from the perspective of its entangled character.

Pierre Nora's work on French lieux de mémoire remains the omnipresent locus classicus in memory studies. It triggered extensive scholarship around the world, notwithstanding all the critiques that have been leveled against it. The disapproval not only of Nora, but also of successive adaptations of his work, have mainly been expressed by memory theorists over the last two decades. The first criticism revolves around the accentuation of unity and homogeneity of memory. Jeffrey $\mathrm{K}$. Olick argues that one example of a misconception ${ }^{4}$ is illustrated by the study

vols. (Paris: Gallimard, 1984-1992); Jan Assmann, Cultural Memory and Early Civilization [1992] (Cambridge, UK: Cambridge University Press, 2011). Referring to an increasing methodological critique of these memory studies, a "third phase" has more recently been postulated by Astrid Erll, "Travelling Memory: Whither Memory Studies," Parallax 17 (2011), 4-18. See also Wulf Kansteiner for an earlier critical voice: "Finding Meaning in Memory: A Methodological Critique of Collective Memory Studies," History and Theory 41, no. 2 (2002), 179-197.

3. Erll, "Travelling Memory," 6. She directs this criticism toward Nora as well as other scholars, such as Jan and Aleida Assmann and Jay Winter. Other examples include John E. Bodnar, Remaking America: Public Memory, Commemoration, and Patriotism in the Twentieth Century (Princeton: Princeton University Press, 1993); Franz Knipping, "Rom, Capitol, 25. März 1957," in Europäische Erinnerungsorte 2: Das Haus Europa, ed. P. den Boer, H. Duchhardt, G. Kreis, and W. Schmale (Munich: Oldenbourg, 2012), 97-104; Stätten grenzüberschreitender Erinnerung-Spuren der Vernetzung des Saar-Lor-Lux-Raumes im 19. und 20. Jahrhundert: Lieux de la mémoire transfrontalière-Traces et réseaux dans l'espace Sarre-Lor-Lux aux $19^{e}$ et $20^{e}$ siècles, ed. Rainer Hudemann, http://www.memotransfront.uni-saarland.de (accessed March 22, 2013); Erinnerungsorte des Christentums, ed. Christoph Markschies (Munich: Beck, 2010); Oldenburger Erinnerungsorte: Vom Schloss bis zur Hölle des Nordens, von Graf Anton Günther bis Horst Janssen, ed. Mareike Witkowski (Oldenburg: Isensee, 2012).

4. Without a doubt, Nora's initial inventory of French lieux de mémoire has led to this misconception, which successive adaptations in various other contexts, mainly of nation-states, have reiterated. See, among others, Dansk identitetshistorie, ed. Ole Feldbæk, 4 vols. (Copenhagen: Reitzel, 19911992); Pim den Boer, “Lieux de mémoire et l'identité de l'Europe," in Lieux de mémoire et identités nationales, ed. Pim den Boer and W. Frijhoff (Amsterdam: Amsterdam University Press, 1993), 11-29; I luoghi della memoria: Personaggi e date dell'Italia unita, ed. Mario Isnenghi, 3 vols. (Rome: Laterza, 1997); Les Lieux de la mémoire: La commémoration du passé au Canada, ed. Thomas H. B. Symons (Ottawa: Société historique du Canada, 1997); Deutsche Erinnerungsorte, ed. Étienne François and Hagen Schulze, 3 vols. (Munich: Beck, 2001-2002); Gedächtnisorte im anderen Amerika: Tradition und Moderne in Québec, ed. Ingo Kolboom and Sabine A. Grzonka (Heidelberg: Synchron, 2002); Memoria Austriae, ed. Emil Brix, Ernst Bruckmüller, and Hannes Stekl, 3 vols. (Vienna: Oldenbourg, 2004-2005); Lieux de mémoire au Luxembourg: Usages du passé et construction nationale, ed. Sonja Kmec, Benoît Majerus, Michel Margue, and Pit Péporté (Luxembourg: Saint-Paul, 2008); België: Eeen parcours van herinnering, ed. Geert Buelens and Jo Tollebeek, 2 vols. (Amsterdam: Bert Bakker/Prometheus, 2008); Schweizer Erinnerungsorte: Aus dem Speicher der Swissness, ed. Georg Kreis (Zurich: Verlag Neue Zürcher Zeitung, 2010); Pim den Boer, "Konzept Europa," in Europäische Erinnerungsorte 1. Mythen und Grundbegriffe des europäischen Selbstverständnisses, ed. Heinz Duchhardt, Georg Kreis, Wolfgang Schmale, and Pim den Boer (Munich: Oldenbourg Verlag, 2011), 59-74, and even beyond the nation: Imagining the City: Memories and Cultures in Cape Town, ed. Sean Field, Renate Meyer, and Felicity Swanson (Cape Town: HSRC Press, 2007) or 
of how a given group remembers a certain event. ${ }^{5}$ Early commentators on Nora's magnum opus had already emphasized that such enquiries are in danger of treating social groups as essential and static entities. ${ }^{6}$ Moreover, the prominent theoretical approaches by Jan and Aleida Assmann, which develop the link between collective memory and group identity, ${ }^{7}$ have been read in a way that contributed further to deriving memory from pre-existing groups. ${ }^{8}$

Although social theorists have emphasized the transcultural dimension of memory, the pernicious stress on unity and homogeneity has not yet been eliminated. It is intuitive to assume independent units of analysis, without paying ample attention to mutual dependence and communication between cases, the "travelling" of narratives, ${ }^{9}$ forms, and practices. ${ }^{10}$ Even comparative studies have not yet succeeded in overcoming the misleading heuristic of unity and homogeneity, although they have acknowledged the problem in theory. ${ }^{11}$

Related to this first criticism, a second flaw is attributed to the treatment of memory as a tangible phenomenon. In line with everyday associations evoked by the term "memory," a prevailing number of empirical studies start from an artifact that is taken to be the embodiment of memory. Numerous contributions take such artifacts as memorials, museums, or novels to be manifestations of memory. ${ }^{12}$ It goes without saying that there is nothing wrong with studying memorials. But, as Olick has pointed out, the postulate that "memory is a thing" is often accompanied by the idea that "collective memory . . . represents or mirrors a prerepresentional past."13 One starts to encounter epistemological difficulties if one takes the study of memory to serve as an access point to allegedly real

Deutsch-Polnische Erinnerungsorte, ed. Hans-Henning Hahn and Robert Traba, 3 vols. (Paderborn: Schöningh, 2012-2013).

5. Jeffrey K. Olick, The Politics of Regret: On Collective Memory and Historical Responsibility (New York: Routledge, 2007), 89-90.

6. Steven Englund, "The Ghost of Nation Past," Journal of Modern History 64, no. 2 (1992), 299-320.

7. Jan Assmann, "Kollektives Gedächtnis und kulturelle Identität,” in Kultur und Gedächtnis, ed. Jan Assmann and T. Hölscher (Frankfurt on Main: Suhrkamp, 1998), 9-19; Jan Assmann and John Czaplicka, "Collective Memory and Cultural Identity," New German Critique 65 (1995), 125-133; Assmann, Cultural Memory and Early Civilization.

8. For instance, Sabine R. Arnold, Stalingrad im sowjetischen Gedächtnis: Kriegserinnerung und Geschichtsbild im totalitären Staat (Bochum: Projekt, 1998).

9. Erll, "Travelling Memory," 12.

10. Michael Rothberg, Multidirectional Memory: Remembering the Holocaust in the Age of Decolonization (Cultural Memory in the Present) (Stanford: Stanford University Press, 2009).

11. A notable exception is the project on Polish-German lieux de mémoire that takes both "parallel" and "shared" constellations into account. See Hahn and Traba, eds., Deutsch-Polnische Erinnerungsorte.

12. This tendency was already prominent in Nora's original collection of French realms of memory, but has been exploited further. Witold Molik, "Das Denkmal der Armee 'Poznań' als regionaler und gesamtpolitischer Erinnerungsort," in Gedächtnisorte in Osteuropa, ed. R. Jaworski, J. Kusber, and L. Steindorff (Frankfurt on Main: Peter Lang, 2003), 26-34; Anna Kaminsky, Erinnerungsorte an die Opfer des Kommunismus in Belarus (Berlin: Metropol, 2011); Alexandra Klei, Der erinnerte Ort: Geschichte durch Architektur: Zur baulichen und gestalterischen Repräsentation der nationalsozialistischen Konzentrationslager (Bielefeld: Transcript, 2011); Christos Varvantakis, "A Monument to Dismantlement," Memory Studies 2, no. 1 (2009), 27-38; Sarah Farmer, "Symbols that Face Two Ways: Commemorating the Victims of Nazism and Stalinism at Buchenwald and Sachsenhausen," Representations 49 (1995), 97-119.

13. Olick, The Politics of Regret, 89. 
events $^{14}$ rather than as interpretations of a past. Thus the dialogue between theoretical work and empirical studies has room for improvement as the current situation leaves the latter unable to employ the suggestions of the former.

In light of the identified problems, this article makes the following four contributions. First, we suggest an inductive approach that starts from the actors' interpretations rather than from artifacts of memory. Second, this shift in perspective permits going beyond an a priori setting of commemorating groups. On the contrary, we stress the entangledness of memory, that is, its (inter-) relational character. Third, the inductive procedure provides an instrument to stimulate the self-reflexivity of memory scholars with regard to their involvement in the construction of memory. ${ }^{15}$ Eventually, the analysis of entanglements, the study of cross-references in acts of remembering, leads to mnemography, a dialogical practice between theory and empirical research.

This article proceeds in three steps. The first section sharpens the perspective on memory and points toward its genuine entangledness. The second section marks off the concept of entangled memory, explicating its dynamic and plural features. Entangledness is identified as being constitutive of memory, and the analysis of entanglements as a promising procedure for investigations in memory research. The third section suggests some methodological tools for analyzing entanglements in their synchronic and diachronic dimensions by taking the paradigmatic case of European memory as an example.

\section{A CONCEPT OF MEMORY}

The first part of this essay articulates the concept of memory that underpins the overall argument. Carving out three conceptual bonds that have accompanied the notion of memory since the beginning of the last century, it defines memory in its relation to a perception of time, an idea of language, and a concept of action.

\section{Memory and Time}

The increasing importance of memory studies since the 1980s has amplified and widened the explanatory claims of this area of research. It seems intuitive to assume a significant overlap of memory and knowledge ${ }^{16}$ or that one could look to use the concept of memory as a general model for thinking. ${ }^{17}$ Whereas

14. Examples can be found in Avner Ben-Amos, "Les funérailles de Victor Hugo," in Nora, Les lieux de mémoire, vol. I: La république, 473-522; Giovanni De Luna, "I fatti di luglio 1960," in Isnenghi, ed., I luoghi della memoria, 359-372; Adam Krzemiński, "Der Kniefall," in François and Schulze, eds., Deutsche Erinnerungsorte, I, 638-653; also Knipping, "Rom, Capitol, 25. März 1957."

15. Nationalizing the Past: Historians as Nation Builders in Modern Europe, ed. Stefan Berger and Chris Lorenz (Basingstoke, UK: Palgrave Macmillan, 2010).

16. Jan Assmann had already formulated a strong parallel between memory and knowledge in an early definition of his concept of cultural memory, "Kollektives Gedächtnis und kulturelle Identität," 9. Later definitions sharpened the concept and weakened this parallel. Today, the distinction between memory and knowledge becomes especially fluid in those contributions that take up the notion of memory as it is formulated in psychology or neurosciences; see, for instance, Harald Welzer, "Was ist das autobiographische Gedächtnis, und wie entsteht es?," Bios 15 (2002), 169-186.

17. For instance, Richard Terdiman, Present Past: Modernity and the Memory Crisis (Ithaca, NY: Cornell University Press, 1993), 8; see also Helmut König, Politik und Gedächtnis (Weilerswist: Velbrück Wissenschaft, 2008), 27. 
such broad approaches lean toward a detemporalized understanding, we argue that entangled memories are best understood if the concept retains a strong link to a constructivist conception of the past, which it had first acquired in Maurice Halbwachs's critique of Henri Bergson's temporal ontology. ${ }^{18}$

As a genuinely temporal concept, memory plays the role of distinguishing between past and present. In the following, memory refers to acts of mental representation in which signs bring something absent to the fore of consciousness. ${ }^{19}$ Acts of remembering differ from other acts of mental representation in that they denote the absent as past.$^{20}$ It is common ground that far from constituting an objective reality; the past, in its "ontic absence ... in itself"21 essentially emerges from present ascriptions with their respective contemporary conditions of knowledge-production and usages of the past. ${ }^{22}$

As long as acts of mental representation do not also carry this irretrievable moment of temporal distance, they operate in the sphere of experience that memory constitutively builds upon. Yet different from experiences, memories are those acts of mental representation by which individuals locate themselves in time and distinguish themselves from the past - a "present past," to use the words of Reinhart Koselleck. ${ }^{23}$ It is also Koselleck who reminds us that this temporal shift sets up a changeable relation between present and past as all interpretations are superposed and altered by newer interpretations. ${ }^{24}$

18. With regard to Halbwachs's critique of Bergson, see, for example, Lutz Niethammer, "Frontstellung und Unabschließbarkeit der Gedächtnistheorie von Maurice Halbwachs," in Erinnerung und Gesellschaft: Mémoire et Société, ed. H. Krapoth and D. Laborde (Wiesbaden: VS Verlag, 2005), 114.

19. These signs are more than mere reproductions against the background of a "crisis of representation"; see Hans Ulrich Gumbrecht, Production of Presence: What Meaning Cannot Convey (Stanford: Stanford University Press, 2004); Winfried Nöth, "Crisis of Representation?," Semiotica 143 (2003), 9-15; Peter Burke, "From Representation to Construction," in What is Cultural History? (Cambridge, UK: Polity Press, 2004), 74-99.

20. Acts of remembering thus conform to the basic hermeneutical structure most prominently called "the structure of something as something" by Martin Heidegger, Being and Time [1962] (Malden, MA, and Oxford: Blackwell Publishing, 2009), 189.

21. John Zammito, "Koselleck's Philosophy of Historical Time(s) and the Practice of History," History and Theory 43, no. 1 (2004), 134.

22. Among others, see Elena Esposito, Soziales Vergessen: Formen und Medien des Gedächtnisses der Gesellschaft (Frankfurt on Main: Suhrkamp, 2002), 7; Moritz Csáky, "Die Mehrdeutigkeit von Gedächtnis und Erinnerung. Ein kritischer Beitrag zur historischen Gedächtnisforschung," in Digitales Handbuch zur Geschichte und Kultur Russlands und Osteuropas, 9 (http://epub.ub.unimuenchen.de/603/1/csaky-gedaechtnis.pdf; accessed July 30, 2012), 8; Daniel Levy, "Das kulturelle Gedächtnis," in Gedächtnis und Erinnerung: Ein interdisziplinäres Handbuch, ed. C. Gudehus, A. Eichenberg, and H. Welzer (Stuttgart, Weimar: Metzler, 2010), 93.

23. As memories can be considered as clustered and layered experiences, their temporal relations constitute themselves as in Koselleck's model of historical experiences; see his "Stetigkeit und Wandel aller Zeitgeschichten," in Zeitschichten (Suhrkamp: Frankfurt on Main, 2000), 246-264, and "'Space of Experience' and 'Horizon of Expectation': Two Historical Categories," in Futures Past (New York: Columbia University Press, 2004), 255-276, as well as "Repetitive Structures in Language and History," in Performing the Past: Memory, History and Identity in Modern Europe, ed. K. Tilmans, F. van Vree, and J. Winter (Amsterdam: Amsterdam University Press, 2010), 51-66.

24. Helge Jordheim has defended Koselleck's theory of mutable and plural historical times against its reduction to a theory of periodization: see "Against Periodization: Koselleck's Theory of Multiple Temporalities," History and Theory 51, no. 2 (2012), 151-171. 
A constructivist conception of the past also applies to the temporal counterpart, the future. As "future present," or even as "future past," it genuinely contains projections from the present. The present thus forms itself in the junction between the space of experience and the complementary horizon of expectation..$^{25}$ In this constellation, present and future are linked in a probabilistic relation that Koselleck has coined "bundles of possibility." ${ }^{26}$ These insights help to apprehend how all tempora of memory underlie a process of continuous historicization. They can be converted into each other via present ascriptions. ${ }^{27}$

\section{Languages of Memory}

Whenever an absent reality is represented as past, it is placed in a distinct, yet mutable relation to other representations. In this relational configuration, memories prove constitutive of meaning. ${ }^{28}$ Memory studies have acknowledged this productive quality ever since Jan Assmann based his theoretical works on Peter L. Berger's and Thomas Luckmann's social constructivism. ${ }^{29}$

The condition of possibility of memory's constructive character is its close link to language, also previously formulated by Halbwachs in $1925 .^{30}$ The subsequent section on "memory's entangledness" will explore this insight by applying a concept of language that is in debt to Ludwig Wittgenstein's Philosophical Investigations. Languages comprise manifold rules and customary patterns for the use of their signs. These determine how linguistic signs are to be used meaningfully and how they create meaning in turn. These signs neither stand in a static or fixed relationship to one another, nor do they form a coherent whole. In consequence, every utterance will present relations of analogy to different prior utterances, instead of being the identical iteration of one specific pattern of language use. Thereby language rules allow for continuity of meaning. ${ }^{31}$

Acts of remembering correspond to speech acts in that the former, too, create meaning through the analogical compliance with existing rules. However, not all speech acts are also acts of remembering. Even if rules always relate an utterance to a prior utterance, only those acts for which the attribution as past is constitutive can be qualified as memory.

25. With a similar impetus, Paul Ricœur, in Memory, History, Forgetting (Chicago: University of Chicago Press, 2004), 443, states: 'A pairing is thus made between 'anticipating' and 'returning,' like the pairing of horizon of expectation and space of experience in Koselleck, but on the level that Heidegger considers to be derivative with respect to historical consciousness."

26. Koselleck, "Die unbekannte Zukunft und die Kunst der Prognose," in Zeitschichten, 206.

27. Ricœur summarizes this process: "Knowing that people of the past formulated expectations, predictions, desires, fears, and projects is to fracture historical determinism by retrospectively reintroducing contingency into history," Ricœur, Memory, History, Forgetting, 382.

28. For the wider significance of the genuine relationality of meaning, see, in particular, Jacques Derrida, "Structure, Sign, and Play in the Discourse of the Human Sciences," in Writing and Difference, ed. A. Bass (London: Routledge, 1990), 278-294.

29. Assmann, Cultural Memory and Early Civilization, 33.

30. Maurice Halbwachs, On Collective Memory [1925] (Chicago: University of Chicago Press, 1992).

31. Hence, this continuity does not reach further than "family resemblance." Ludwig Wittgenstein, Philosophical Investigations: Philosophische Untersuchungen [1953] (Cambridge, MA: Blackwell, 2009), §67. 
If Wittgenstein inspired social theorists to imagine languages as forms of life, ${ }^{32}$ this also invites memory scholars, such as Moritz Csáky, to think of language as a model of memory. ${ }^{33}$ The emphasis on the linguistic embeddedness of memory does not mean that only written texts or utterances qualify as memory. As a model, the notion of language equally illuminates mnemonic qualities of artistic or performative practices. Just like utterances, these practices constitute meaning by analogical compliance with rules or wider patterns of use and therefore constitute languages of memory. ${ }^{34}$

\section{Acts of Remembering}

The patterns of preceding interpretations of the past, which allow for a continuity of meaning, place every individual interpretation of the past in a social context. In accordance with Wittgenstein's "private language argument," 35 we assume that "[a]n 'inner process' stands in need of outward criteria." 36 Continuous meaning emerges where rules or patterns provide a social reference point for comparison and lead to their coherent application. It is widely acknowledged that acts of remembering, drawing upon Halbwachs, constitute faits sociaux. ${ }^{37}$ Thus ensues the genuine social nature of memory without implying either the existence of a collective subject or of a cognitive core, ${ }^{38}$ although social frames of remembering remain dependent on individual consciousness as its carrier. If memory refers to the relation between individual and collective memory, it is essential to avoid overemphasizing an alleged polarization between the two. The analogy between social facts and memory acknowledges the coercive power of memory upon the individual without neglecting the productive dimension of memory as mentioned above.

Inasmuch as every interpretation of the past reiterates or distinguishes itself from social rules and patterns, it presents itself as an act of remembering. Far from drawing a line between the silent imagination of a past experience and

32. Ibid., §19. For a first adaptation in social theory see Peter Winch, The Idea of a Social Science and its Relation to Philosophy (London: Routledge, 1990).

33. Csáky, "Die Mehrdeutigkeit von Gedächtnis und Erinnerung," 13-15.

34. This formulation points to J. G. A. Pocock's conceptualization of political languages; see John G. A. Pocock, "The Concept of a Language and the métier d'historien: Some Considerations on Practice," in Politics, Language and Time: Essays on Political Thought and History (London: Methuen \& Co, 1971).

35. Wittgenstein, Philosophical Investigations, §§243-315. Cf. Gordon P. Baker and Peter Michael Stephan Hacker, "On Misunderstanding Wittgenstein: Kripke's Private Language Argument," Synthese 58 (1984), 407-450; Crispin Wright, "Kripke's Account of the Argument against Private Language," Journal of Philosophy 81 (1984), 759-778; Edward Craig, "Meaning and Privacy," in A Companion to the Philosophy of Language, ed. B. Hole and C. Wright (Oxford: Blackwell, 2006), 127-145.

36. Wittgenstein, Philosophical Investigations, §580. For an extended discussion, see John Hunter, "Wittgenstein on Inner Processes and Outward Criteria," Canadian Journal of Philosophy 7 (1977), 805-817.

37. In declaring memory a fait social, Halbwachs shifted the emphasis for the study of memory toward memory's social embeddedness and its specific social reality. Building upon Durkheim's principle of association, memory is furthermore not simply the sum of its individual components since "the group is differently constituted than the individual." Émile Durkheim, "The Rules of Sociological Method," in Readings from Emile Durkheim, ed. K. Thompson (Chichester, UK, London, and New York: E. Horwood; Tavistock Publications, 1985), 65.

38. Halbwachs emphasized this point in his less known but nevertheless important English article "Individual Consciousness and Collective Mind," American Journal of Sociology 44 (1939), 815. 
the lively commemorating gesture in the presence of other human beings, the expression "act of remembering" points to a specific quality of any mental representation of the past. This quality of memory as a social action is therefore less illuminated by the accompanying bodily expressions of an interpretation, than by its relation to the languages of memory that constitute its context.

\section{MEMORY'S ENTANGLEDNESS}

In the following section we suggest a theoretical frame that distinguishes between different analytical perspectives. We will demonstrate that acts of remembering are heterogeneous, dynamic, and therefore genuinely entangled.

\section{The Mnemonic Signifier}

Just like other faits sociaux, acts of remembering undergo processes of objectification and thus gain independence from the particular temporal and spatial context from which they stem. Among others, Jeffrey K. Olick has emphasized the need to perceive of these objectifications without reifying memory.$^{39}$ Insofar as acts of remembering are a phenomenon of discourse, their objectifications are a semiotic phenomenon. We therefore suggest designating these objectifications as mnemonic signifiers, which can refer to any socially relevant figuration of memory. ${ }^{40}$ For instance, studying the entangled memories of Versailles, and therefore understanding Versailles as a mnemonic signifier, permits going beyond an analysis of Louis XIV's castle as a simple building and the changes in its architectural composition over time. Rather, its symbolic character comes to the fore. At different points in time, Versailles could be a metaphor for French absolutism, American independence, or German defeat in the First World War, all based on the attribution as past. Evidently, its physical substance lacks any relevance $a$ priori in this research setting. The meaning of Versailles unfolds only in considering the context of concrete acts of remembering. ${ }^{41}$

Different interpretations, distant in time and space respectively, of the same mnemonic signifier ascribe changing meanings to it. By virtue of this, a mnemonic signifier forms the intersection of different mnemonic signifieds. Insofar as the mnemonic signifier enables relating different interpretations, it provides access to the discourse of memory, its comprehensibility and social scope. Memory studies must go beyond writing factual histories of mnemonic signifiers in favor of extending their investigations to the history of interpretations or, as we suggest calling it henceforth, mnemography.

\section{Memory's Plurality}

Departing from single acts of remembering, an investigation of memory can recover one of the central potentials of Halbwachs's writings, which has not yet

39. Olick, The Politics of Regret, 104.

40. Peter L. Berger and Thomas Luckmann, The Social Construction of Reality: A Treatise in the Sociology of Knowledge (Garden City, NY: Doubleday, 1967), 33-34.

41. Friedemann Pestel, "Versailles als memory building-Memory-building mit Versailles" in Europäische Erinnerung? Gruppenübergreifende Erinnerung jenseits der Nation, ed. G. Feindt, F. Krawatzek, D. Mehler, F. Pestel, and R. Trimçev (Göttingen: V\&R Unipress, forthcoming 2014). 
been fully exploited, namely the plurality of memory at any given moment: ${ }^{42}$ "[J]ust as people are members of many different groups at the same time, so the memory of the same fact can be placed within many frameworks, which result from distinct collective memories." 43 This quotation points to the first of two modes of memory's plurality. Acts of remembering insert an actor into different social frames, for instance, class, religion, family, or academia. As Csáky develops in reference to Mikhail Bakhtin, all interpretations of the past are themselves polyphonic. ${ }^{44}$ Developing the idea of languages of memory, meaning is created through simultaneous analogies to different utterances and not by identical iterations of one prior utterance. Similarly, acts of remembering stand in an analogical relation to different conventionalized patterns of interpretation. ${ }^{45}$ Thus acts of remembering convey an actor's simultaneous belonging to different social frames. ${ }^{46}$ Memory's plurality, however, is not expressed solely in the polyphony of single acts of remembering; as its second and related mode, we suggest studying the plurality of competing acts of remembering.

If memory is understood as a plural phenomenon, its presumed unity reveals itself as a "pernicious postulate." ${ }^{47}$ On the contrary, a mnemonic signifier is the juncture of concurrent interpretations with an unlimited variety of possible constellations. In this discursive field of plurality, the actors' struggles for visibility and recognition organize and diminish the variety and influence of other interpretations. In these moments of conflict, the heterogeneous character of memory comes most visibly to the foreground. Indeed, competing interpretations are not equally visible at different moments in time. Though unsuccessful interpretations are constitutive for the space of possibility, they become hard to notice beyond situations of contestation. Thus, when the contested field of memory has been narrowed through hegemonic closure, interpretations no longer need to display their social reference points. Dominant interpretations tend to eradicate their signs of being an action.

Since memory scholars wish to understand the meaning of an actor's intervention in the field of memory, subject positions are of primary hermeneutic value. The analysis of subject positions includes their localization in time and space, their self-conceptions and normative attitudes, as well as their material and sym-

42. Halbwachs concludes his earlier work on the social frameworks of memory by stating similarly: "The individual calls recollections to mind by relying on the frameworks of social memory. In other words, the various groups that compose society are capable at every moment of reconstructing their past. But, as we have seen, they most frequently distort that past in the act of reconstructing it." Halbwachs, On Collective Memory, 182. This puts his in sharp contrast to other notions of memory that were discussed around the turn of the twentieth century; see Félix Krawatzek and Rieke Trimçev, "Eine Kritik des Gedächtnisbegriffes als soziale Kategorie," Jahrbuch für Politik und Geschichte (Wiesbaden: Franz Steiner Verlag, 2013).

43. Halbwachs, On Collective Memory, 52.

44. Csáky, "Die Mehrdeutigkeit von Gedächtnis und Erinnerung," 13-15.

45. Such an approach to the social realm has nowadays found influential expression in the concept of over-determination; see Ernesto Laclau and Chantal Mouffe, Hegemony and Socialist Strategy: Toward a Radical Democratic Politics (London: Verso, 1985), 113.

46. Gilles Deleuze and Félix Guattari, A Thousand Plateaus (Minneapolis: University of Minnesota Press, 1987). The plurality of actors is brilliantly summarized in the opening: "The two of us wrote Anti-Oedipus together. Since each of us was several, there was already quite a crowd.” Ibid., 3 .

47. Olick, The Politics of Regret, 92-97. 
bolic resources. They permit scrutinizing social structures or cultural patterns that suggest specific expectations of social appropriateness that have to be met by actors of memory. Their analysis helps in understanding the conflictual and productive dimension of memory: on the one hand, actors compete against one another about their discursive positions; on the other hand, their interpretations are transmitted to following generations.

Combined attention to both modes of memory's plurality can avoid a onedimensional approach to actors of memory, which promisingly links memory studies to current debates in social theory. Following Ernesto Laclau and Chantal Mouffe, actors can speak from only one of the subject positions that every single act of remembering implies. ${ }^{48}$ As a remembering individual assumes different subject positions at a given moment, the category of actor itself serves as an analytical instrument. Only on this level can it fill the gulf between constructivist voices in memory theory and the pitfall of factual history characterizing much of empirical research.

\section{Memory's Dynamics}

As Astrid Erll has recently pointed out: "[m]emories do not hold still — on the contrary, they seem to be constituted first of all through movement." ${ }^{49}$ In other words, interpretations of mnemonic signifiers are also variable over time. Erll invites us to pay more attention to "the "travels' of memory," its carriers, media, contents, practices, and forms. "[T]he reconstruction of its routes," ${ }^{50}$ though, would justly require insights into the interplay of these dimensions, an interplay that Erll stays relatively silent about. The following suggestions on diachronic mnemonic entanglements take up the debate at precisely that point.

In virtue of their coercive and preserving power as well as their enabling and renewing potential, discursive structures in the field of memory are constantly being reshaped. The relationship between structures and acts translates into the relationship between the single act of remembering and the social frame, which contains one of the most promising insights that can be developed from memory studies..$^{51}$

The density of mnemonic rules determines the coercive power of a frame of memory. ${ }^{52}$ Institutionalization ${ }^{53}$ increases density through repetition or linkage to existing discourse logics, for example, of the social or legal realm. If an act of remembering does not conform to the mnemonic rules that constitute a social

48. Laclau and Mouffe, Hegemony and Socialist Strategy, 115.

49. Erll, "Travelling Memory," 11 .

50. Both citations ibid.

51. An exemplary illustration of this relationship has been given by Daniel Levy and Natan Sznaider, who reflect on the relationship of Holocaust memory and the social frame of Jewish diaspora in The Holocaust and Memory in the Global Age (Philadelphia: Temple University Press, 2006), $39-54$.

52. This property of memory is shared by the coercive power that social facts exercise, which depends upon the punishment that is related to its violation. Durkheim, "The Rules of Sociological Method," 68.

53. This is to be understood in the aforementioned wide sense including, for example, monuments, widely used textbooks, regularly rebroadcast TV programs. 
frame, sanctions may be observed.$^{54}$ In a process of negotiation, deviations from existing rules of memory can lead to an evolution of mnemonic frames and the composition of the respective social group.

One of the current challenges for memory studies is certainly the dissolution of the classical frame of memory, the nation-state, which is highlighted by the turn toward non- and transnational frames, as debates on European or global memory illustrate. Although it is common ground to acknowledge this development as such, assessment of its implications has yet to reach a consensus. A first scenario presents the emerging reconfiguration of mnemonic frames as a synthesis of previous ones, ${ }^{55}$ whereas a second scenario emphasizes the "multidirectional" character of memory. It sees this new frame as one of many complementary possibilities, without necessarily substituting for the previous ones. ${ }^{56}$ Such older patterns may stay unchanged, but only if they are continuously re-enacted. Diachronically evolving interpretations of one mnemonic signifier compete against one another just as synchronically conflicting interpretations do. Entanglements therefore emphasize the interactions among different patterns of interpretation related to one mnemonic signifier.

A further occurrence of diachronic entanglements consists in the impact of interpretations of different, previously institutionalized, mnemonic signifiers. A present-day experience is thus shaped by mnemonic patterns even before it is itself understood as past. This becomes clearest when one thinks about current experiences of everyday life. Even though they are not interpreted as past, sense is made of them with reference to mnemonic appropriations of the past. Investigations of memory may increase their explanatory potential by studying former memories based on experiences as "interpreting appropriations of lived reality." 57

The following chart presents a schematic overview of the idea of entangled memory. It goes without saying that this two-dimensional illustration cannot entirely do justice to the complexity of the phenomenon.

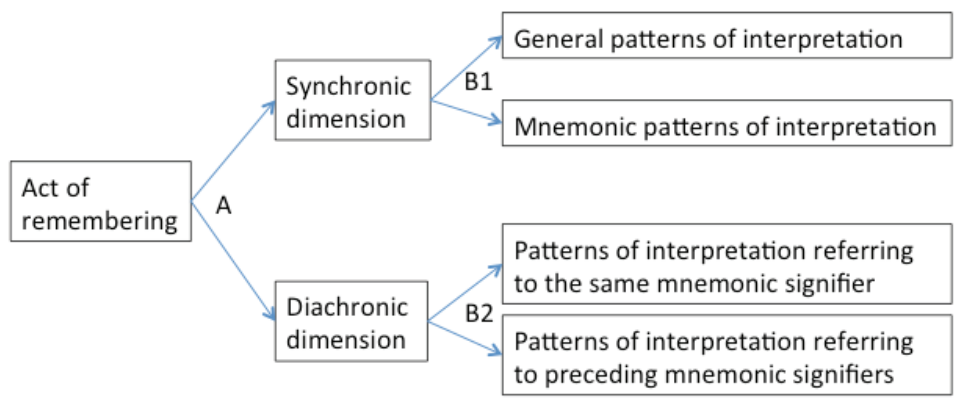

Figure 1: Entangledness of Memory

54. Sanctions on memory exist in various forms. Regarding the example of the genocide against Armenians in 1915, which largely framed discourse both in and outside Turkey, see Levy and Sznaider, The Holocaust and Memory in the Global Age, 153.

55. This response can be found in den Boer, "Konzept Europa."

56. Rothberg, Multidirectional Memory, 1-18.

57. Original in German: "Deutende Aneignung gelebter Wirklichkeit." Jörn Leonhard, "Europäisches Deutungswissen in komparativer Absicht: Zugänge, Methoden und Potentiale," Zeitschrift für Staats- und Europawissenschaften 4 (2006), 348, our translation. 
The analysis of an act of remembering (knot A) can be differentiated into a synchronic and a diachronic dimension. Different and even competing synchronic patterns of interpretation shape the interpretations of the mnemonic signifier. These synchronic patterns (B1) guide and limit possible interpretations by referring to specifically mnemonic patterns, or to general patterns of interpretation. The latter are those that do not satisfy the criterion of "as past," such as political ideologies, religious doctrines, or judicial norm systems.

A similar twofold modality characterizes the diachronic dimension of the acts of remembering (B2): on the one hand, they iterate interpretations of the same mnemonic signifier from different points in time. On the other hand, this signifier may also be related to earlier mnemonic signifiers, and establish continuity with preceding interpretations. Every act of remembering stands simultaneously in a relation of either iteration or alteration to several of these diachronic patterns. The first case, referring to alterations of patterns of interpretation concerning mnemonic signifiers, is of particular importance, as these alterations are the vehicle of change in the sequence of interpretations of the past.

Summarizing the twofold quality of memory as being plural and dynamic, single acts of remembering are to be understood as being entangled. The concept of entangled memory refers to the genuine entangledness of interpretations and actors, illustrated by the different branches in the figure. This insight calls for the analysis of detectable entanglements, taking into account multiple perspectives, asymmetries, and cross-referential mnemonic practices ${ }^{58}$

Entangled memory therefore integrates insights from comparative historical research, the study of cultural transfers, and especially histoire croisée as initially formulated by Michael Werner and Bénédicte Zimmermann. ${ }^{59}$ Responding to the demand for an inductive process-relational research approach, we propose an analysis that does not rely on categories established a priori, but centers on the categories used by the actors themselves. Therefore the differentiation between synchronic and diachronic dimensions, as mentioned above, is merely a heuristic device. It would be misleading to understand these perspectives as separated. Much to the contrary, diffusions across time and space are constitutive for entangled memory. Bringing them to the forefront will deepen our understanding of the construction of memory as encountered in the public realm.

58. Cf. earlier usage of this term by Sebastian Conrad, who shares our criticism of homogeneous and nation-centered research agendas, but understands entangled memory as a specific constellation of postwar Germany and Japan. Sebastian Conrad, "Entangled Memories: Versions of the Past in Germany and Japan, 1945-2001," Journal of Contemporary History 38 (2003), 85-99.

59. Michael Werner and Bénédicte Zimmermann, "Beyond Comparison: Histoire Croisée and the Challenge of Reflexivity," History and Theory 45, no. 1 (2006), 30-50; Sebastian Conrad and Shalini Randeria, "Geteilte Geschichten: Europa in einer postkolonialen Welt," in Jenseits des Eurozentrismus: Postkoloniale Perspektiven in den Geschichts- und Kulturwissenschaften, ed. Sebastian Conrad and Shalini Randeria (Frankfurt on Main and New York: Campus, 2002), 9-49; Comparative and Transnational History: Central European Approaches and New Perspectives, ed. Heinz-Gerhard Haupt and Jürgen Kocka (New York: Berghahn Books, 2009); James Mahoney and Dietrich Rueschemeyer, Comparative Historical Analysis in the Social Sciences (Cambridge, UK, and New York: Cambridge University Press, 2003). 


\section{MEMORY'S ENTANGLEMENTS}

Having developed memory's entangledness as a first dimension of entangled memory, the following section works out its second dimension, memory's entanglements. We will discuss four heuristic devices that help tackle the interactions between acts of remembering in space and time. Consequently, we shift from a theoretical to a research-oriented perspective. Finally, the concept of entangled memory will be exemplified drawing on contemporary academic debates on European memory in order to prove its potential for memory studies.

\section{Access to Memory}

Memory is always bound in its own temporal context, which is the present. This insight can likewise be applied to memory researchers and their access to memory, as researchers are actors of memory. Thereby memory studies operate in the "fusion of horizons" between past and present-day experience, which for Hans-Georg Gadamer marks the possibility of understanding.$^{60}$ Reflecting upon the recent scholarly interest in European memory, it is obvious that contemporary political concerns make this topic meaningful. For instance, Małgorzata Pakier and Bo Stråth have pointed to the rejected proposal of a European constitution as one motivation for their investigation. ${ }^{61}$ Though we admit that the present is significant to the hermeneutical process, the question of how it shapes the historical analysis remains to be explored.

Contrary to the historical process of layering interpretations, mnemography suggests an inversion of temporal relations: as research questions are drawn from the present, the diachronic depth unfolds from the most recent interpretation as past. Departing from this contemporary point of access, and following its references to other mnemonic voices, the identification of older interpretations follows a chronology against time. However, this principle in turn proceeds forward: the reconstruction of a mnemonic signifier calls for tracing subsequent mnemonic interpretations in time. This reconstructive analysis explains how certain interpretations became dominant against others, and demonstrates how later interpretations reappropriate earlier ones anew. This inverted process establishes continuity between two temporal poles - the earliest and the most recent interpretation - and those in between.

As the point of access is not arbitrary, the earlier distinction between experience and memory is merely relational. The translation of experiences into memory implies a change of temporality from present to past, which corresponds to a shift in attribution from as present to as past. Consequently, the appropriation of

60. See Esposito, Soziales Vergessen, 7, and for Hans-Georg Gadamer's Horizontverschmelzung, see Truth and Method (London: Sheed \& Ward, 1975), 299-305.

61. Małgorzata Pakier and Bo Stråth, "Introduction," in A European Memory: Contested Histories and Politics of Remembrance, ed. Małgorzata Pakier and Bo Stråth (New York and Oxford: Berghahn Books, 2010),1-2. Quite similarly, Claus Leggewie and Anne Lang reveal their motivation in Der Kampf um die europäische Erinnerung: Ein Schlachtfeld wird besichtigt (Munich: Beck, 2011), 7. 
the present shifts over time to new interpretations in new presents. As memory research scrutinizes the layering of experiences and memories, this temporal transformation calls for consideration in scholarly work. Even though memory studies often rightly point to their temporal context of origin, this point of access needs further reflection, as it shapes the analysis throughout the investigation. Integrating this relational position of researchers will not overcome the situational constraint of research, but will enable the analysis to deepen its understanding of how memory is constructed.

\section{From Plurality to Mnemonic Conflicts}

Having recognized that memory scholars establish continuity and discontinuity between different interpretations, we now explore how the polyphonic constellation of actors in time is represented in memory scholarship. We do this by conceptualizing conflict as an analytical tool for memory research.

Europe, characterized "by its cultural differences, contradictions, multilingualism ... which develop into an equivocal and polyphonic memory," constitutes a preeminent terrain for researching plurality. ${ }^{62}$ In general, two understandings of the conflictual character of European memory can be distinguished. In the first understanding, European memory is conflictual because it is a memory of the "disasters of the short $20^{\text {th }}$ century." ${ }^{63}$ In the second understanding, European memory is conflictual because it is the place of conflicts of interpretation. Claus Leggewie and Anne Lang, prominent German-speaking contributors to the debate on European memory, explore both aspects, which distinguishes theirs from most other contributions that concentrate merely on the first dimension, and sometimes neglect conflict all together. ${ }^{64}$ However, even though they employ conflict as an analytical core concept, the empirical findings are not used to reconceptualize European memory accordingly.

The heuristic use of plurality in contributions on European memory would nevertheless benefit from a more refined understanding of the conflict dimension of memory. Leggewie and Lang present conflict as something that is to be overcome $^{65}$ through an increased Europeanization of memory, a scenario that conforms to their own normative ideals. ${ }^{66}$ Such a teleological approach risks

62. Moritz Csáky, Das Gedächtnis der Städte: Kulturelle Verflechtungen-Vienna und die urbanen Milieus in Zentraleuropa (Vienna: Böhlau, 2010), 121 (our translation). Concentrating primarily on Central Europe, Csáky has also emphasized the need to transpose this property of memory to a wider European scale, "Die Mehrdeutigkeit von Gedächtnis und Erinnerung," 22.

63. Leggewie and Lang, Der Kampf um die europäische Erinnerung, 9 (our translation).

64. Some of these other contributions endeavor to fill a European memory container. For instance, the recent Europäische Erinnerungsorte admit the existence of plurality on a conceptual level, but most empirical contributions fail to exploit this characteristic: Pim den Boer, Heinz Duchhardt, Georg Kreis, and Wolfgang Schmale, "Einleitung," in Duchhardt, Kreis, Schmale, and den Boer, eds., Europäische Erinnerungsorte 1, 7-12. Similarly, and with a more starkly pronounced normative impetus, Étienne François refers to the necessity of enforcing the project of a European society united by a shared memory of critical junctures, such as the Second World War, which can be fostered through common commemorative events: Étienne François, "Europäische lieux de mémoire," in Transnationale Geschichte: Themen, Tendenzen und Theorien, ed. G. Budde, S. Conrad, and O. Janz (Göttingen: Vandenhoeck \& Ruprecht, 2006), 290-303, especially 300.

65. Leggewie and Lang, Der Kampf um die europäische Erinnerung, 52 and 185.

66. Ibid., 23 and 27. 
denying the inherent polyphony of memory, where different voices constantly interact in multiple conflictual sites. Though scholarship on European memory exposes the different voices that surround any lieux de mémoire, the existence of such different voices is perceived as an exception, signaling the incomplete Europeanization of memory.

The research approach developed in this article suggests analyzing the manifold conflicts on European memory free from a teleological frame geared toward ending mnemonic conflicts. Rather than searching for homogeneous European lieux de mémoire, an investigation of European memory may benefit from concentrating on actors and their strategies ${ }^{67}$ that contributed to the emergence of European interpretations as well as their interaction with older patterns of interpretation. ${ }^{68}$ This requires investigating an actor's struggle to establish the dominant interpretation by marking other interpretations as inappropriate, illegitimate, or simply wrong. ${ }^{69}$ Building upon memory's entangled character, the following elements are to be taken into consideration: the social acceptance of the interpretation, the social appropriateness of the spokesperson's position, the control of resources, and the capacity for institutionalization.

Although memory scholarship does expose plurality, attention to synchronic conflicts usually gets lost. This is particularly true when the homogenizing experience of the nation-state with its capacity to unite narratives is transposed on the supra-national level. The outstanding resources and the coercive power of political entities have only too often obscured the polyphony of memory conflicts. Publications on national lieux de mémoire as well as state-sponsored research agendas charged with Aufarbeitung of the past emphasize the strength and primordial role of political entities. ${ }^{70}$ Such a relationship is to some degree duplicated at the European level with scholars investigating the existence of European memory, sometimes supported by EU funds. This unavoidably contributes to the shaping of their object of study. Since memory scholarship wishes to

67. The notion of strategy here refers to Foucault's concept of a theoretical principle of order and constitution of segments of discursive formations. See Michel Foucault, Archaeology of Knowledge [1969] (London: Routledge, 2002), 71-78.

68. For case studies based on this approach, see Europäische Erinnerung? Gruppenübergreifende Erinnerung jenseits der Nation, ed. Gregor Feindt, Félix Krawatzek, Daniela Mehler, Friedemann Pestel, and Rieke Trimçev (Göttingen: V\&R Unipress, forthcoming 2014).

69. Means for this range from conventions of inappropriateness to coercive measures like judicial sanctions that constitute difference.

70. This is obvious for Germany where Aufarbeitung of the Nazi past is an ongoing process. A recent study on the Auswärtiges Amt triggered a new debate. Eckart Conze, Norbert Frei, Peter Hayes, and Mosche Zimmermann, Das Amt und die Vergangenheit: Deutsche Diplomaten im Dritten Reich und in der Bundesrepublik (Munich: Karl Blessing Verlag, 2010). In Central and Eastern Europe, it is the communist past that is frequently and controversially negotiated. State-financed Institutes of National Remembrance, such as, for example, the Polish Instytut Pamięci Narodowej, exert strong influence on interpretations of the past. Michal Kopeček, "In Search of 'National Memory': The Politics of History, Nostalgia and the Historiography of Communism in the Czech Republic and East Central Europe," in Past in the Making: Historical Revisionism in Central Europe after 1989, ed. Michal Kopeček (Budapest: CEU Press, 2008), 87-91. Similarly in Spain, the representation of franquismo in public spaces remains a controversial issue, as the debate on the 2007 Ley de memoria histórica showed. Carolyn P. Boyd, "The Politics of History and Memory in Democratic Spain," Annals of the American Academy of Political and Social Science 617 (2008), 133-148. In France especially, this led to an appeal of historians against legal authorities restricting interpretations of history out of political interests. “Appel de Blois," Le Monde, November 10, 2008. 
contribute to a better understanding of the complexity and contradictions within modern society and its dealings with the past, the scrutiny of different synchronic conflicts must be one of its core elements.

\section{Constellations of Generations as Layers of Memory}

Following upon the idea of memory's entangledness, the synchronic dimension of memory cannot be studied without taking into account its diachronic depth. Therefore, the foregoing analysis of actors in time leads to the question of how to study them over time. Here generations, understood as functional units of reception, interpretation, and transmission of experiences and memories,$^{71}$ provide a heuristic for differentiating group constellations. For an exploration of this potential, we will address the generational embeddedness of memory scholars in Western and Eastern Europe and their reactions to the processes of European integration after 1945 to demonstrate how debates on European memory are themselves influenced by generational dynamics.

Although this embeddedness has not yet raised much attention, memory scholarship has nonetheless brought "generations" into play as a heuristic concept for studying temporal change and - though not explicitly - as an explanation for how the Assmannian transition from "communicative" to "cultural" memory actually works in its continuity. ${ }^{72}$ In particular, German scholars studying the Third Reich and Holocaust memory, such as Ulrike Jureit, Helmut König, and Harald Welzer, have shown the ways in which contemporaries and descendants differ in their mnemonic patterns by projecting experiences and expectations on the mnemonic signifier. They have worked out how growing temporal distances lead to a successive historicization and increase the importance of mediation that no longer refers to "lived reality," but to appropriations as past. ${ }^{73}$ However, the generational interplay on a political, social, and academic level, for example in memory laws, NGOs, or research projects, calls for further consideration of the possibility and limits of layering experiences.

European memory-building processes draw extensively on transmitted experiences of the Holocaust and the Second World War. However, the academic literature tends not to go beyond studying the transmission and universalization of this negative founding myth or the ways in which societies come to terms with their pasts after experiences of dictatorship and totalitarianism. Though generational constellations have been acknowledged as important for studying historical actors, their importance has not yet been applied to memory research itself. It would be illuminating to question the extent to which the broadening spatial frames in the investigation of founding myths of European memory are the effect of generational trends in memory studies themselves.

71. Urike Jureit, Generationenforschung (Göttingen: Vandenhoeck \& Ruprecht, 2006).

72. Assmann, Cultural Memory and Early Civilization.

73. Ulrike Jureit, "Generationen als Erinnerungsgemeinschaften," in Generationen: Zur Relevanz eines wissenschaftlichen Grundbegriffs, ed. Ulrike Jureit and M. Wildt (Hamburg: Hamburger Edition, 2005), 244-265; König, Politik und Gedächtnis, 497-637; Harald Welzer, Sabine Moller, and Karoline Tschuggnall, Opa war kein Nazi: Nationalsozialismus und Holocaust im Familiengedächtnis (Frankfurt on Main: Fischer Taschenbuch, 2002). 
A preliminary attempt to historicize memory research brings to the fore a symptomatic asynchrony between European integration as an institutional answer to the rupture of 1945 and the emergence of the second and third wave of memory studies. It is striking to observe that the response to an accelerating cooperation among the Western European states between the 1950s and 1980s initially consisted in a defensive national backlash, most clearly illustrated by Pierre Nora's lieux de mémoire. Nora, one of the very few actual contemporaries of the Second World War among memory scholars, was followed up by a more "European" generation. Historians like Étienne François, Hagen Schulze, or Heinz Duchhardt, who by their research records and academic careers transcended national boundaries, took over the task of adapting Nora's project to other national frames. They soon became aware of the cross-referential dimension of their objects of study, which corresponded to their own biographical experiences. By this awareness these scholars contributed considerably to the Europeanization of memory studies, converging recently in the Europäische Erinnerungsorte that bring together Nora's paradigm of an inventory of memory and an implicitly Western-modeled framework of European integration. By including the turning point of 1989/91, Pim den Boer and his coeditors also partly incorporate the Central and Eastern European experience into this setting.

Meanwhile a new generation of memory scholars has been socialized both in permeable networks of European academic exchange and in institutions that directly result from European integration. Their main interest, however, does not seem to consist any more in taking an inventory of European landscapes of memory. ${ }^{74}$ Instead, they take the European either as a starting point for pluralizing its conceptual framework or for studying it as one spatial entity among others, thus aiming at analyzing acts of remembering on a global level. Furthermore, the eastward enlargement of the EU has transformed Europe as a category, provoking different reactions to the long-dominant Western paradigm in memory studies. ${ }^{75}$

Most tellingly, this phase shift between European integration and its repercussions in memory studies takes place within the "window" of living generations, or, in other words, the "living link" 76 between actors who differ in their relation to the mnemonic signifier. Generations carry and continue established forms of memory and become actors in new processes of institutionalization, leading to new mnemonic patterns. Studying generational constellations therefore permits situating historical experiences in time and also helps to mark academic trends as such. Thus, the paradigm of European memory not only encompasses the three

74. Dépasser le cadre national des "Lieux de mémoire": Innovations méthodologiques, approches comparatives, lectures transnationale, ed. Benoît Majerus, Sonja Kmec, Michel Margue, and Pit Péporté (Brussels: P.I.E. Peter Lang, 2009).

75. Polish memory studies argue for a rediscovery of older scholarly traditions that have until now been neglected by Western memory studies. See, for instance, Kornelia Kończal and Joanna Wawrzyniak, "Polskie badania pamięcioznawcze: Tradycje, koncepcje (nie)ciągłości," Kultura $i$ Społeczeństwo 55, no. 4 (2011), 11-63.

76. This phrase by Halbwachs had already been articulated by Johann Gustav Droysen in the 1850s in the heyday of historicism. Halbwachs, La mémoire collective, 50; Johann Gustav Droysen, Historik (Stuttgart: Frommann-Holzboog, 1977), I, 89. 
levels of temporality - past, present, and future - but also their shifting horizons of possibility that undergo a continuous historicization.

\section{Memory-building and Academia}

Unlike Halbwachs's historicist understanding of history as a holistic entity that can be distinguished from memory, ${ }^{77}$ we wish to stress that the historical analysis of interpretations produces interpretations on its own. Memory scholarship, therefore, becomes an integral part of the mnemonic practices in its own time and may considerably influence both present and future memory discourse. ${ }^{78}$ Memory scholars face the contradictory expectations of disciplinary habits, academic conventions, and their social embeddedness. Therefore, by imparting the results of academic research to a wider audience, mnemography narrows the "bundles of possibility" of future developments of memory. Rather than claiming hermeneutic objectivity, or re-essentializing an idea of historical truth by a neopositivist approach to sources,${ }^{79}$ mnemography has to contextualize its theoretical premises and methodological tools in their historical and political contingency.

The interdependence of experience, memory, and mnemography calls for a threefold reflection that has been exemplarily demonstrated by Csáky. Starting from a deconstruction of current mnemonic patterns, which also involves academic discourse, this reflection, then, allows confronting them with the mnemonic patterns of previous actors. Finally, their reconstruction constitutes an academic contribution that is aware of its constructive character ${ }^{80}$ It becomes clear that, in principle, the rules of academic discourse permit researchers to take a detached view of dominant patterns of interpretation since the synchronic and diachronic interpretations that constitute the objects of study provide a heuristic tool of distantiation. Accordingly, memory scholars call for a systematic contextualization of their own discursive interventions, for instance in contributing to historical committees, in counseling museums, or in distributing resources for research. Self-reflexivity does not aim to overcome the social embeddedness of

77. Halbwachs, La mémoire collective, 68-74; following up on this idea, see Philippe Martin, "Des lieux de mémoire pour l'Europe une mission impossible?," in Majerus et al., eds., Dépasser le cadre national, 169.

78. Michel Espagne, "Kulturtransfer und Fachgeschichte der Geisteswissenschaften," in Kulturtransfer und Vergleich, ed. M. Middell (Leipzig: Leipziger Universitätsverlag, 2000), 48; Dirk Schlinkert, "Der Zeitzeuge: Eine Spurensuche im Übergang zum kulturellen Gedächtnis," in Die Zukunft der Erinnerung, ed. M. Grieger, U. Gutzmann, and Dirk Schlinkert (Wolfsburg: VolkswagenAktiengesellschaft, 2008), 54.

79. This claim is widely recognized; see, for example, Christian J. Emden, "Nation, Identität, Gedächtnis: Überlegungen zur Geschichtlichkeit des Politischen,” in Arbeit am Gedächtnis: Für Aleida Assmann, ed. M. C. Frank and G.. Rippl (Munich: Fink, 2007), 63-85; Erll, "Cultural Memory Studies"; Otto Gerhard Oexle, "Memoria als Kultur," in Memoria als Kultur, ed. Otto Gerhard Oexle (Göttingen: Vandenhoeck \& Ruprecht, 1995), 9-78. Whereas Martin, "Des lieux de mémoire pour l'Europe une mission impossible?," 160, refers to history as a philosophical meta-concept, Werner Paravicini defends a holistic understanding of historical truth. Die Wahrheit der Historiker (Munich: Oldenbourg, 2010), 38.

80. Csáky, "Die Mehrdeutigkeit von Gedächtnis und Erinnerung," 11-13; see also Kornelia Kończal, "Geschichtswissenschaft," in Gudehus, Eichenberg, and Welzer, eds., Gedächtnis und Erinnerung: Ein interdisziplinäres Handbuch, 256. This present-based approach corresponds on the level of chronological time with Koselleck's triptych of Aufschreiben, Fortschreiben, and Umschreiben. "Erfahrungswandel und Methodenwechsel," in Zeitschichten, 41-53. 
memory scholars, but to integrate it into a methodological framework that may place memory studies beyond performative self-contradiction.

In Europäische Erinnerungsorte, Pim den Boer held a mirror up to the debate on European memory. ${ }^{81}$ As a conceptual historian and memory scholar, he traces the crossings of the history of the concept "Europe" and the memory regime of the Western nation-state. The changing complementary and opposing functions of references to Europe within national memory-regimes elucidate the contingent nature of the particular role that invocations of Europe play in current debates on memory. Den Boer bluntly acknowledges that the furthering of a European political solidarity constitutes the contested horizon of expectation of such invocations ${ }^{82}$ Exemplifying the benefits of historical distantiation, this analysis also helps to sharpen the challenges of self-reflexivity. Den Boer is far from joining in the chorus of those who use constructivist epistemologies for the invention of a collective European memory. Yet he also admits that the aim of such a historical investigation is to "recharge the concept of Europe with a retrospective dimension." At this very moment, the author's consciousness of the memory-building effects of academia turns into a debatable act of academic memory-building. Though a historical analysis is also an act of remembering, its language of memory is characterized by the consciousness of its own rules. This self-reflexive consciousness leaves no ground from which these rules can be understood as superior to the rules of other languages of memory. From the perspective of mnemography, the insightful historical distantiation realizes self-reflexivity only insofar as it subscribes to a principle of self-restriction.

As long as conceptual approaches tend to reiterate the methodological implications of the Halbwachs-Nora amalgam by applying it to other frameworks, the value of memory studies basically consists in new empirical findings within a shared episteme. This imminent danger of the memory paradigm, though, stands in contrast to its persistent appeal for public debate and academic donors.

As memory is not all-encompassing, memory studies can only explain what works within the logic of certain interpretations as past-and not factualities. Taking this conditio sine qua non seriously, memory studies deal with diachronically contingent objects of research that are subject to a twofold historicization: both on the level of content and on the level of analysis.

These heuristics of entangled memory do not call for a new "mnemonic turn," but claim to shed new light on the relevance of the actors' own interpretations for the constitution of mnemonic patterns that frame the researchers' analytical instruments in order to go beyond a continuous inventory of lieux de mémoire.

\section{CONCLUSION}

The aim of this article is to confront the question "Whither memory studies?" by sketching a possible path for an enhanced dialogue between theoretical reflection and empirical operationalization. We introduced the notion of entangled memory to help memory studies navigate toward its promising third wave and move

81. den Boer, "Konzept Europa."

82. See also den Boer, Duchhardt, Kreis, and Schmale, "Einleitung," 8. 
beyond the current bias toward homogeneity and tangibility. With this intention in mind, a specific understanding of memory has been put forward: We argued that the concept of memory refers to interpretations that, first, present experiences as past; second, attribute meaning to this "present past" through the analogical compliance with manifold rules and wider patterns of interpretation; and third, by virtue of that dependence on a social reference point, are to be understood as acts of remembering.

On this conceptual ground, we have elaborated the genuine entangledness of acts of remembering. In a synchronic perspective, memory's entangledness expresses itself in a twofold plurality. Every act of remembering inscribes an individual in plural social frames. This polyphony entails, furthermore, the simultaneous existence of concurrent interpretations of the past. In a diachronic perspective, memory's entangledness manifests itself in the dynamic relations between single acts of remembering and changing mnemonic patterns. Memory scholars, therefore, uncover boundless configurations of cross-referential and overlapping interpretations. We have suggested that this difficult terrain can best be tackled if the symbolic objectification of acts of remembering becomes the organizing device of study. This mnemonic signifier is the heuristic tool for inducing relations between various acts of remembering that are distant in time and space.

The theoretical insights in memory's entangledness call for the analysis of empirical entanglements. Though this article has not aimed at a rigid translation from theory into a universally applicable methodology, we wanted to take into account the challenge of operationalization. In this respect, four heuristics have been outlined that help to make use of an analysis of entanglements for a more pertinent understanding of memory: the access point to memory being the researchers' present, a focus on moments of conflicts, systematic attention to the role of generations, and, finally, the contextualization of memory scholarship in the mnemonic practices of its own time.

How, in the end, would a third wave of memory studies, informed by a concept of entanglement as outlined in this article, distinguish itself from previous waves? After extending its reach to additional national entities, the memory paradigm has witnessed, over the last ten years, an opening to non-national constellations. Nevertheless, this far-reaching expansion has drawn extensively on previous epistemological grounds. As a consequence, memory studies might have moved beyond the nation-state, but did not move beyond the latter's close linkage to questions of identity and legitimacy.

Mnemography approaches this novel constellation as an opportunity to confront new challenges and simultaneously bend backward to look at one's own scientific practice. The broadening spatial frames sharpen the attention for complexity and alterity, and invite scholars to think about heterogeneity not merely as a flaw, but as a constitutive feature of the ways in which processes of remembering form social bonds. Emphasizing memory studies' strength in interdisciplinary exchange, we have referred to concepts that have already proven valuable within recent debates in social and historical theory. 
The notion of entangled memory suggests a different answer to the continuous public demand for memory. This normative horizon of expectation points not only toward shifts in customary patterns of legitimacy, but has also imparted a lot of its vigor to the evolution of the memory paradigm. Though the awareness of its rules acknowledges the constructive character of its own scientific practice, these rules continue to bind mnemography, which thereby suggest self-restriction. The premise of memory's entangledness presents itself as a hermeneutic corrective, resistant to both reifying essentializations and the quest for new holisms. Aware of its own embeddedness, mnemography can exemplarily dispute those "present pasts" that come to serve as instances of legitimacy, but never ultimately seize such instances, as it is restricted to what memory is constituted of: contingent interpretations of actors.

In this perspective, the new directions of the third wave of memory studies reach beyond the field itself, reflecting broader processes of change and the most crucial debates in the humanities. Entangled memory might serve as a tool to take up this challenge and contribute to an increased dialogue between disciplines.

Rheinische Friedrich-Wilhelms-Universität Bonn (Feindt)

University of Oxford (Krawatzek)

Goethe Universität Frankfurt (Mehler)

Albert-Ludwigs-Universität Freiburg (Pestel)

Universität Hamburg (Trimçev) 